Stakes for measuring accumulation, ablation and movement of 'Amitsulôq ice cap' have been drilled into the ice this summer. Next field season it is the intention to extend the stake net and supplement the ablation measurements with runoff measurements at the front of the 'base camp glacier'. It is also the intention to drill stakes in Tasersiaq gletscher. Together with measurements already started at Qapiarfiup sermia at $65^{\circ} 36.3^{\prime} \mathrm{N}, 52^{\circ} 9.3^{\prime} \mathrm{W}$ this will give a profile ranging from the more humid coastal environment to the relatively arid climate near the Inland Ice margin.

\title{
References
}

GTO 1980: Grønlands Tekniske Organisation, Forundersøgelses \& byplanafdelingen, Vandkraft Grønland, Undersøgte bassiner September 1980.

\section{Glaciological investigations at Qamanârssûp sermia, West Greenland}

\author{
Ole B. Olesen \& Roger J. Braithwaite
}

As part of the GGU programme for the regional mapping of the hydropower potential of West Greenland, glaciological and climatological investigations were continued on the Qamanârssûp sermia (inventory number 1CH21002) in 1981. The station was first established in late summer 1979 (Olesen, 1981) so that records for two whole summers are now available.

\section{Fieldwork}

The field programme included measurement of transient balance in a network of twenty stakes extending from about 80 to $1300 \mathrm{~m}$ above sea level. The more remote stakes could only be visited a few times during the season, while daily readings were made at three stakes, the '751' stakes, on the glacier near to the base camp. Because of the delayed arrival of the field party in early June and possibly because May was exceptionally warm considerable ablation had already occurred on the lower parts of the glacier before the start of measurements. Consequently, it was not possible to determine separate winter and summer balances. However, on a short visit in early March it was observed that there was no winter snow on the glacier below about $1000 \mathrm{~m}$ so the observed annual balances probably reflect the annual ablation patterns quite closely.

In addition to the mass balance readings, the stake positions were surveyed in mid June and late August by intersection from fixed points on the bedrock. Analyses of the results will allow estimates to be made of 'winter' and 'summer' velocities. 


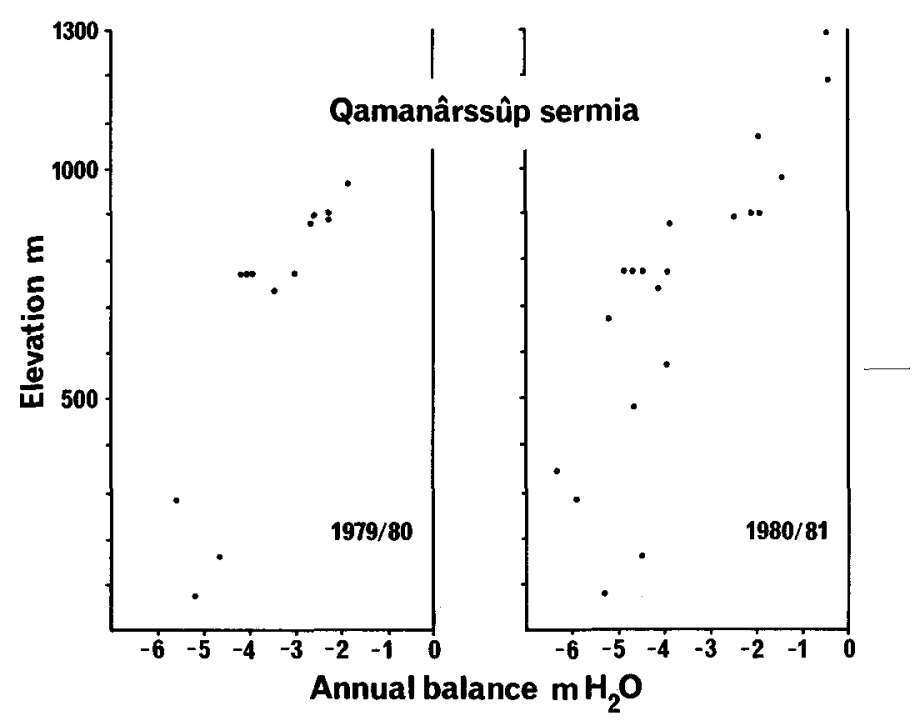

Fig. 31. Annual balances plotted against elevation for the Qamanârssûp sermia, $1979 / 80$ and $1981 / 81$. The balance year is 1 st September to 31st August.

Routine measurements of simple climatic elements, e.g. temperature, humidity, wind and sunshine, were continued at the base camp while a thermohygrograph station was maintained at roughly the same elevation in the middle of the glacier. New additions to the programme in 1981 were the twice-daily readings of evaporation from a Type-A pan and the continuous recording of global radiation at the base camp.

\section{Results}

Preliminary results for the 1980/81 annual balances are plotted against elevation in fig. 31 together with the corresponding 1979/80 values. The data refer to a balance year extending from 1 September to 31 August. As the actual measurement periods for individual stakes are rather irregular, some adjustments had to be made to the data to fit them to a common time interval. For the purpose of these interpolations, the daily readings from the ' 751 ' stakes provided a useful key.

Although the 1980/81 annual balances shown in fig. 31 are based upon an extended stake network compared to the $1979 / 80$ data, they show some similar features. For example, in both years there appears to be relatively low ablation near the snout of the glacier, while there is a maximum in the elevation range $300-400 \mathrm{~m}$ followed by a general decrease above about $700 \mathrm{~m}$.

A summary of the main climatic elements for 1981 in comparison with those for 1980 are given in Table 5. In addition to monthly temperatures, precipitation and sunshine duration, approximate figures for the mean ablation of the '751' stakes are also given. From the table it is clear that the 1981 season was warmer and wetter than 1980 in both June and July, and was colder and wetter in August. Except for June, there was much less sunshine in 1981. However, there was slightly more ablation in 1981 . The greater warmth of July 1981 seems to be the main cause. 
Table 5. Climatological and glaciological data summary for base camp, Qamanârssûp sermia 1980 and 1981

\begin{tabular}{|c|c|c|c|c|}
\hline & JUNE & JULY & AUGUST & SUMMER \\
\hline \multicolumn{5}{|c|}{ Monthly mean temperature $\left({ }^{\circ} \mathrm{C}\right)$} \\
\hline 1980 & $4.7^{\mathrm{a}}$ & 6.6 & 5.5 & 5.6 \\
\hline 1981 & $5.2^{\mathrm{b}}$ & 7.5 & 3.9 & 5.5 \\
\hline Difference & +0.5 & +0.9 & -1.6 & -0.1 \\
\hline \multicolumn{5}{|c|}{ Month/y precipitation $(\mathrm{mm})$} \\
\hline 1980 & 20 a & 61 & 64 & 145 \\
\hline 1981 & 65 b & 110 & 81 & 256 \\
\hline Difference & +45 & +49 & +17 & +111 \\
\hline \multicolumn{5}{|c|}{ Sunshine duration (hrs) } \\
\hline 1980 & $(226)$ & 258 & 327 & 811 \\
\hline 1981 & $(252)$ & (214) & 124 & 590 \\
\hline Difference & +26 & -44 & -203 & -221 \\
\hline \multicolumn{5}{|c|}{ Mean ablation of three ' 751 ' stakes $(\mathrm{mm})$} \\
\hline 1980 & $(910)$ & 1330 & 1010 & 3250 \\
\hline 1981 & $(1110)$ & 1860 & 800 & 3770 \\
\hline Difference & +200 & +530 & -210 & +520 \\
\hline
\end{tabular}

$a$ based on 26 days of record.

$b$ = based on 29 days of record.

0 = adjusted to full month.

\section{Future outlook}

Because of the difficulties of determining runoff from the Qamanârssûp sermia itself, an attempt was made to install a water-level recorder in the outflow from the glacier $1 \mathrm{CH} 21001$ which is immediately to the north of Qamanârssûp sermia. However, when the recorder was established in mid-June the streamflow was already too strong to allow the sensor to be fixed to the stream bed. Hopefully, this can be remedied in early 1982 so that a full runoff record will be collected for next summer. Some extra stakes should also be drilled into glacier $1 \mathrm{CH} 21001$, both for comparison with the runoff from that glacier and with the balances on Qamanârssûp sermia.

An earlier start to the 1982 fieldwork is also indicated for determination of separate winter and summer balances as well as for the extension of the stake network into the accumulation area above about $1400 \mathrm{~m}$.

From the point of view of the long-term GGU objective of glacier runoff assessment in West Greenland, the results from 1980 and 1981 indicate both greater amounts and more irregular patterns of ablation than expected (Braithwaite, 1980). The proper inclusion of these effects in future runoff models must be attempted.

\section{References}

Braithwaite, R. J. 1980: Regional modelling of ablation in West Greenland. Rapp. Grønlands geol. Unders. 98, $20 \mathrm{pp}$.

Olesen, O. B. 1981: Glaciological investigations at Qamanârssûp sermia, West Greenland. Rapp. Grønlands geol. Unders. 105, 60-61. 